\title{
THE EFIECT OF ANTIHISTAMINIC DRUG ON TUBERCULIN REACTION
}

ELNG SOO HAN, M.D.

Seoul, Jiorea

\section{Ministry of IIealth,} INTRODUCTION

It is wcll known that antihistaminic drugs have a marked effect on the manifestations of allergy. Considerable interest has been raised as to the effect that this set of crugs could have on the intrackrmal tuberculin reaction in man and animals. Many workershavestudied the subject recently in this respect, but the resuit: of thier investigations have been divergent and have reatt:d sharp controversies.

Bouquet (1) and Sarber (2) have made investigations on anjmals. Bouquet

(1) obtained on appreciable in!ibitory effect on the tulerculin reaction of guinea pigs by using different kinds of antihistaminies. On the other hand, Sariber (2) obtained marked reduction of the tuberculin reaction both in size and intensity.

This controversy evoked further interest whichr esulted in the clinical investigations by Henclerson and Jorld(3) ar itenderson (4). The latter workers gave large doses of Pyribenzamine or similar groups of arugs daily for as long as six months and claimed that inhibitor $y$ effect was obtained. They went one step further to say that it: was possible to produce marked clinical improvement in tuberculous pneumonia and exudative lesions in this way. They cmoloyed 30 such cases for their study and of these 18 cases showed improvement. Sumnession of the tuberculin reaction, they found, was reversod within 4-6 weeks after the discontinuation of the antihistaminic druss. Graub and Barrist (5) supported the above results and concluded that the tuberculin testing shruld not be done when antihistaminic drugs are being administ ered. The opmosite conclusion was arrived at by Crine, Levine and Aaron (6) and Friedman and Silberman (7). Ilunter, Davis and Hyde (8) mentioned that antihistaninic drugs such as pyribenzamine and Benatryl produced no effect whatsoever either on the tuberculin reaction or on the pulmonary process. In a recent letter to the ecilicors of American Review of Tuberculosis, (9) made the suggestion mone would not. expect drugs recommended for use in the
Foot Note; 1. This experimertal study was made in February 1951 at the North Carolina Sanatorium, McCain, N.C., U.S.A:

2. Tuperculosis Controller,
Repubiic of lierea

3. This paper was read at the First Medical Session, Korean Tubercnilosis Association, Seoul in November 7, 1953 
nylactic type of allergic reaction to have munh effert on the delayed, tulercuiin type of reaction."

Fecanse of the varied opinions and controvetisics existing on the sulject, re-investyation anpeared worth while. Tre contusion on this subject should be of greit impontance lecause of the extensive we of these drugs $(10$ a, b.) jartio cuarly during witler and spring.

PAKT I IRELIM NARY IEXIERIMIENT

A prelinima experment was conducted to deternine the esperimental closage of antihistaminicis as well as to olsserve elinical sice dfects following adu inistration of varions an ourt of antihistamin ics.

\section{METIICT OF INVESTIGATION}

Antilistan ince ortgs: Pyrilenzanine tallei (N, N-Dinctlyl-N1 - l enzylN' (alpha-pyriaryl) ethylene lianine hyd ochlorse. Cibat Ihamalcutical Products, 50 ngrni, each.

Patients; Tlese alde all patients in diffcrent phases of proved tulcroulusis at the Nerth Carolina Sanatorimm, McC ain, N.C. Tuberculin Test; Old Tubereu lin was used thr uglout the entire study. Old Tuberculin was diluted in phys:olegic salt solution, $1-10,000$. The technique and interpretation as outlined by the National Tuberculosis Association, 1950, were followed. Reaction ard diameter of rodness ar dinduration were carefully recorded in millineters. finy decrease of more than 5 millimeters in diameter was considered as inhibition.

Dosages: Large dose group received 400 mgn a day in four divided doses.
Medium dose group received $200 \mathrm{rman}$ a day in four divided desses.

Small dose group received $50 \mathrm{mgmi}$ a day.

Fxperiments were divided into two major groups as follows:

1. Premedicated Group

Antilistaninies given prior to tuber. culin test.

a. Tomg term group: A 7-day fxriod of medication prior to skia test and continued for 48 hour while observing: shin test.

i. I.arge duse groub:

2. Mediun close yroup:

3. Small close group:

b. Short terme group: A 2-day period of medication perior to the slin test and continued for 18 huurs while observing skin test.

1. Large dose group:

2. Medium dose group:

3. Snall dose group:

II. Non-Pre-Medicaled Group

Antihistaminies were not given pior to skin test but given with slin test and continued for 18 hours while : kin test was observed.

1. Large dose group:

2. Meclium dise group:

3. Small dose groun:

These patients had not received any lind of antihistaninic: drugs for a prriod of at least there weeks prior to the inverigation. Huwever, individual patients received their routine regiment or dirug thera py such as Streptomicin or ParaAminosalicylic Acid compouncis regardless of this observation.

RESULTS

1. Pre-Medicated Croup 
Table 1 and 2 show the results st long and short term grouns respectively.

\section{TABLE 1. \\ Long term groun}

Name of pati. Results (18 hours) \& Dosage gro. Before Med. After Med.

a. Large close groun)

$\begin{array}{lll}\text { J.N. } & 5 \times 8 & 15 \times 18 \\ \text { w.J. } & 15 \times 18 & 13 \times 1 / 40 \times 45 \\ \text { S.H. } & 12 \times 12 & 12 \times 16\end{array}$

b. Medium dose group

$\begin{array}{lrr}\text { B.W. } & 10 \times 10 & 8 \times 10 \\ \text { T.A. } & 12 \times 12 & 32 \times 35 \\ \text { A.G. } & 11 \times 13 & 10 \times 10\end{array}$

c. Smail dose group

$\begin{array}{lll}\text { H.J. } & 12 \times 12 & 14 \times 15 \\ \text { D.S. } & 22 \times 25 & 7 \times 14 / 70 \times 90 \\ \text { R.S. } & 12 \times 12 & 14 \times 15\end{array}$

There were no anpreciable inlibitory effects after tje recication regardless of the cosage of antihistaminic drugs used in tlis series.

TABIE II

Short term groun

Name of pati.

Results ( 48 hours)

\& Dosag: gro. Before Med. After Med.

a. lange dose group
G.M.
$15 \times 15$
$20 \times 22$
A. W.
$1.2 \times 16$
$8 \times 10$
H.J.
$10 \times 10 / 15 \times 22$
$14 \times 15$

b. Medium dose group.

$\begin{array}{lcc}\text { P.O. } & 12 \times 12 / 24 \times 38 & 17 \times 20 / 25 \times 15 \\ \text { D.J. } & 12 \times 14 & 15 \times 15 \\ \text { C.W. } & 6 \times 6 & 101.0 \times\end{array}$

c. Small dosegroun

$\begin{array}{lrc}\text { W.E. } & 22 \times 24 & 15 \times 21 / 25 \times 15 \\ \text { I..G. } & 6 \times 6 & 10 \times 12 \\ \text { B.D. } & 7 \times 7 & 6 \times 6 / 12 \times 18\end{array}$

In the large dose groun two of three cases showed remarkable reduction in their size of reaction, though one case showed increase in size of reaction. Ilowever, theré were no appreciable inhibitory effects among the groups which received medinm and small doses.

\section{Non-pre-Medicaled Group}

Table 3 shows that no appreciable inhibitory effects regardless of the dosages, except one case in the small dose group M. R.

\section{TAIBIS: 3}

Name of pati. Results (481rours)

\&: Dosage gro. Before Med $\Lambda$ fter Med.

a. Inrge dose group,

$\begin{array}{lcc}\text { T.T. } & 12 \times 13 & 12 \times 15 \\ \text { J.L. } & 12 \times 12 & 14 \times 16 \\ \text { H.F. } & 13 \times 13 / 45 \times 50 & 17 \times 18 / 45 \times 55\end{array}$

b. Medium close group.
l...s.
$8 \times 8$
$14 \times 15$
I.R.
$12 \times 17$
$18 \times 24$
E.W.
$12 \times 13$
$17 \times 20$

c. Small dose groun

$\begin{array}{ccc}\text { C.W } & 10 \times 10 & 13 \times 15 \\ \text { M.R. } & 15 \times 16 / 42 \times 60 & 22 \times 25 \\ \text { D. C. } & 15 \times 16 & 18 \times 20\end{array}$

SIIIE REACTIONS OR...

-.ANTIHISTAMINICS

Table 4 shows the side reactions caused by the antihistaninic drugs with the different doses used. Except one case, throughout the study the antihistaminic usied was l'yribenzantinc. One case $T$. $T$. was treated with Benadryl as he develop. ed severe reactions within one hour after 
or the forst dose of a 100 myan of Pyri-

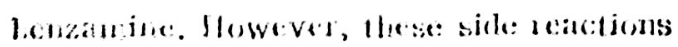

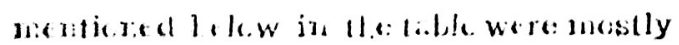

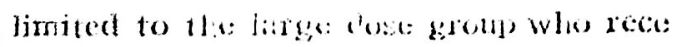
ived daily ato nith, hat a few amoligs thes group who acesived nedium dose (socalled clinical resage, of a $200 \mathrm{mgrm}$ laily atso showed uroomfortalse side reactjons to a minor degree. No such sick: reactions were seen in lie sanall dest group who received daily arage ot 60 nisn?.

These sice reations promptly disappeared ather lhe discontinuation of nesdication with to undesirables symptconns.

\section{Tiliti: 4}

Symid Daily Megrea of No. of I'rsent toms dosiage reation Calsess

Ver-

\begin{tabular}{|c|c|c|c|c|}
\hline $\mathrm{lig}_{\mathrm{g} 0}$ & 40omgn. & Selio: & 3 & $27.3 \%$ \\
\hline & & $\begin{array}{l}\text { Moulcialtuly } \\
\text { Sovere: }\end{array}$ & 2 & 18.205 \\
\hline 4 & & Milla & 3 & \\
\hline & $200 \mathrm{~m} / \mathrm{sm}$ & $\begin{array}{l}\text { Miveleraclely } \\
\text { Siverat }\end{array}$ & 1 & $11.1 \%$ \\
\hline & & Mild & 3 & $33.3 \%$ \\
\hline Rest- & 4Cls & scvere & 3 & $27.3 \%$ \\
\hline $\begin{array}{l}\text { tess- } \\
\text { Mess }\end{array}$ & & $\begin{array}{l}\text { mocirately } \\
\text { sever }\end{array}$ & 2 & $18.2: 0$ \\
\hline & & Mild & 1 & $9.0 \% 0$ \\
\hline & $2 C C_{n} ! n$ & $\begin{array}{l}\text { dioderately } \\
\text { severe }\end{array}$ & 3 & $11.1 \%$ \\
\hline Ilead. & $400 \mathrm{mgm}$ & Stevert & 3 & $27.3 \%$ \\
\hline ache & & Mild & 1 & $9.0 \%$ \\
\hline $\begin{array}{l}\text { Anor. } \\
\text { exa \& } \\
\text { Natusea }\end{array}$ & $\begin{array}{l}200 \text { nigm } \\
?\end{array}$ & 2 Mild & 1 & $11.1 \% 0$ \\
\hline Fever & $400 \mathrm{mg}$ & $\begin{array}{l}\text { above } \\
100^{\circ} \mathrm{F}\end{array}$ & 1 & 900 \\
\hline
\end{tabular}

\section{IISCUSSION}

Pyridenzamine in large closes produced undesirable clinical side reatctions such as dizzintess, heallache, restlesshiess, anorexia and ligh fever but those symptoms promptiy disalppeared shortly after the discontinuation of the medication. It was found that $200 \mathrm{mgm}$. daily apjearod to be adequate to comblact this juvestigation.

It was noted that Pyribenzanine does not cility any significant role in influenteing the tubersulin reaction one waty of tic other. However, a $400 \mathrm{rngm}$. daily riose of Pyiljenzamine fior a short period of two ciays bior to the skin tc:t slowed natided indibitory effect. The rimater of patierts invesigated in this series are fow and tie how ledge arrived at thengh such all fied runb-

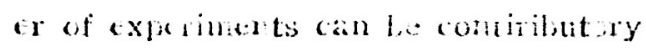
wly in a sllall neasum to a linal contclusion. Therefore, a furtle $r$ inevestigstion

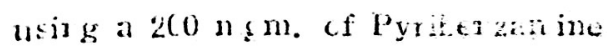
daily on a large number ef patients i:s planed as following ontlired;

\section{PART II. MAIN LXPRRIMLNT}

Finerintertal groups were civiced into thee major garops as wulined in

ale frolin in ary stecy; Pre-Mericated

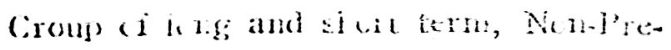
Medicated gromp and Control Cinctep el non-medicated but luberculin trist wats remeated alongs with the experiaturai gromes.

1'.l'. (Purified lowrin lerivatives), Sahrị \&: Dolnte No. Alol, first strength, 0.00002 mign was used irstead of Old Tui,creulin and reacticn was measured in millineters and otherwise, the experimestal methods are exsorly followed the: prelininary stuly. In andition to the above described, couph and sputum were carefully studied to observe the pationts clinical course following nedication. RESUI.TS

\section{PRE-MEDICATLI; CROUP}

Talje 1 and 2 show the results of 
lons tern and short term groups

resinctively.

\section{Table 1: Ions term group TR. Reaction}

Name Scx Before 4 After Cough Sput. Med. $\because$ Med.

\begin{tabular}{|c|c|c|c|c|}
\hline$W . A$ & $M$ & $12 \times 15$ & $1 r \times 11$ & - \\
\hline M.E. & $M$ & $18 \times 25$ & $14 \times 14$ & 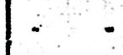 \\
\hline B.J. & $M$ & $18 \times 2 ?$ & $14 \times 15$ & \\
\hline F.P. & $M$ & $13 \times 14$ & $11 \times 12$ & \\
\hline A. $G_{.}$ & $M$ & $12 \times 15$ & $8 \times 10$ & \\
\hline$A . W$. & F & $65 \times 70$ & $50 \times 60$ & \\
\hline I.M. & li & $22 \times 27$ & $22 \times 38$ & \\
\hline $\mathrm{I} . \mathrm{J}$ & $F$ & $13 \times 13$ & $21 \times 10$ & $\cdot$ \\
\hline IS. L. & F & $22 \times 22$ & $15 \times 40$ & - \\
\hline C.G. & $\mathrm{F}$ & $52 \times 60$ & $74 \times 75$ & - \\
\hline
\end{tabular}

In seneral, there is no appreciable inhibitory effects after the medication, although four of them showed slight: decrease and another four of them showed increse in the size of tubcrulin reaction.

Table 2: Shot term gromb)

TR. Livaction

Nane Sex Before 4 Afee Cough Sput. Med. Merl.

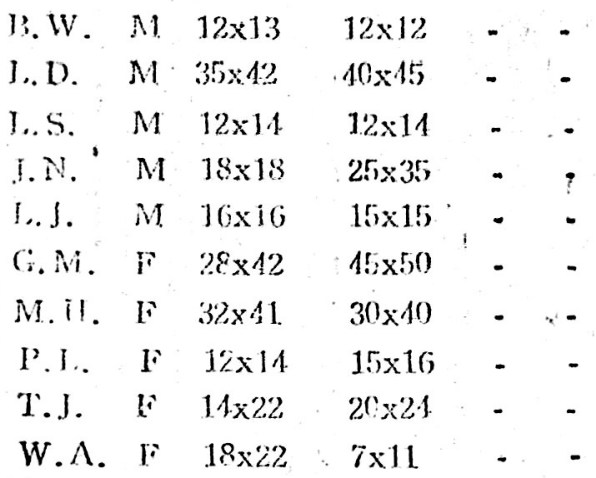

In general, tlucre is $\mathrm{y}$ apprecinble inhibitory effects after the medication, although one of them showed increase: in the size of tuberculin reation. II. NON-PRE-MEIICATEI GROUP Table 3 shows the results of nonPRe-medicated grome.
Table 3:Non-pre-Medicaled Group TR. Reaction

Name Sex Jefore 4 After Cough Spu Med. Med.

H.J. $M{ }^{2} 23 \times 27 \cdot 12 \times 12$

C. $\Lambda$. M $1.3 \times 13 \quad 15 \times 15$

T.I. M $32 \times 34 \quad 28 \times 35$

L. E. M $28 \times 30 \quad 34 \times 45$

S.F. M $14 \times 22 \quad 20 \times 22$

B.A. IF $22 \times 27 \quad 20 \times 28$

M.J.. F $14 \times 18 \quad 14 \times 16$

R.IE. F $20 \times 24 \quad 11 \times 14$

A.N. IF $18 \times 18 \cdot 10 \times 10$

B.C. If $17 \times 17 \quad 11 \times 12$

There weres some inlibitory effect observed that four of ten cases slowed consiclerable decrease and one showed increase in their size of reaction. III. CONTROL GROUP

Table 4 shows the control group which did not: receive ally clrug but tuherculin test was repeated along with the experimenteal promps.

Table 1: Control Group TR. Reaction

Name Sex Jefore Nfter Coung Sinu Med. Med.

II.J. M $15 \times 16 \quad 13 \times 24$

R.S. M $18 \times 19 \quad 32 \times 12$

1). $T$. M $28 \times 55 ; \quad 18 \times 21$

I. J:. $M 45 \times 75 \quad 45 \times(6)$

S.W. M $26 \times 38 \quad 40 \times 70$

T.T. F $5 \times 7 \quad 6 \times 6$

H. L. F. $22 \times 24 \quad 18 \times 18$

C. I. F, $15 \times 15$;1 111

N.H. F $19 \times 19 \quad 10 \times 11$.

i.J. IF $20 \times 20$ 55x76

In feneral, there is sio consiclerable .Aifferest in the size of tuberculin reac(io) in repeated test, allhough two of them showed focrease and another tivo of them stowed increase in the ir sizo of, 
skin reaction ard ren ailing of six of lluan slowed asse tially unclath fed. miscussion

The atverlising: canterign to IMijularizt: the antilistaminic drugs $(10-a,-b)$ lias resulled in llicio exlonsive lue tix the tratment of the common cold amb

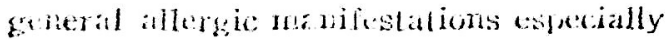
during winter and stming. A correct howwledire regarding the effect of this

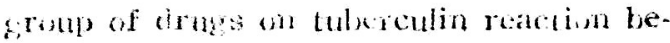
cones esstatititl. Several articles oa thes sibliject both on anirual and lumants lave given riste to contraversial onjinions.

As a peliminary study jocicateit, there has been no aljureciable effects on tuberculin raaction one way or the ollest. however, this study was carried out on the limited small numbers. There. fore, it an be contributory only in at shall measure to a final corclusion so that the sturly was exfench do investigate will latger remblers bising the nust contmem dosage in practice to mininize the chinical toxic mandestatrons.

14: stwral, there is no alpheriable inhibitory effects on tuberculin reaction comsidering the variations seen in the size of tuberculin reaction on contul grobue although minor variations observed on each group.

This study left the inoression that there is no clinical improvement in the chest condition buring or after the nedication. Although this conclu ion cannot be considered as totally onosed to the fondings of frenderson and Judd (3) because they made their obstrvation after giving antihistaminic drug for a period six months and larger doses.
Wlareas, in this stuly, the longen wast icntion: was or a 7-daty perion :hat the dubses were smatler, the anthol, lejirev-

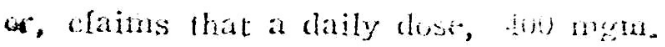
or daore of antihistaninge drugs, was lobe hazardons becausio of toxicity.

\section{CONCLUION}

The flocts of antihistamine erugs on the intrademal tuerculin freaction on froved tulerculosis cases wis stud ited.

1: Gontully speaking, Pyrilengmine does not play any significate inhibus. "ry eject on tubercelin reation.

2. Iarse dose of Pyribenzanine smell-as daily $400 \mathrm{mgm}$ or mere probuca un. desiabe side ractions but propetly disappear followirg discontination of the metication.

Achowwliderinent

Thu author wishes to expess his siacere appreciation to Dr. HE. S. Willis. Saperinter dent of the Nerth Carolime

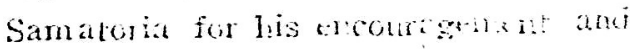
advice.

\section{ROERENCES:-}

1. Buquer, A.: Substances antilistaniniques at raftions tuberculiniques, Ann Inst. Pasteur, 1943, Vol. t?, p. 55

2. Sarber, R.W: Effects of Reradryl Mudrechloride on the Tuberculin reaction in Guincal Pigs, Am. Rev. Tuberc., 1918, Vol. 57, P. 501.

3. Jidd, A.R. and Tunderson, A. R.: The use of antihistaminic: drugs in fuman tuberculosis: A Preliminary Report. Ann. Allergy, 1!) 9 , Vol. 7, P. 306.

4. Exnclerson, A.R.: The liffect of 
antihistamine medication on the tuber. culin reaction. Am. Rev. Tuberc, 1349, Vo1. 60, P. 811.

4. Graub; M. anb larrist, E.: The Effect of $\Lambda$ ntilistaminic Jrugs upon the 'Tubercurin Rcaction. $\Lambda \mathrm{m}$. kev. T3., Vo1. (i1. P. 735, 1950.

16. Cripe, L.E., Jevine, M. L. and Aaron, T. II.: Inhibition of Tuberculin Type of Reaction by Antilistaminic Drugs and Rutin. $\Lambda$ m. Rev. TH., '1943, Vol. 5\%, I'. 701.

7. Fricdnan, E. and Silberman, I.: The Effect of Antihistamine Mexlication on the Tuberculin Reaction in Chilien. Am. Rev. TB., 1949, $\left.V_{0} ! !, 60,1\right) .354$.

8. Jon Hunter, J. D., Javis anb Lcroy Hyige: Tl; Jifect of Antibistamjuic on ite 'Tubreulin keaction. An!. Rov. TT., 62. 525, 1950.

9. Woblouff, C. Ii. : Amtilistaminics arlithe Tuberculin Reaction, $\mathrm{Am}$. liev. T33., 1950, 6ì, p. 555.

10.- a. Folitcrial: Antihistaminics for Colcis, J. ^. M. A. FCb. 25, 1950 , $162: 570$.

b. Revort of the Council on Jharmacy and Clemistry: Status Report on Antilistaminic Agents in the Propylaxis and Treatment of Common Cold, J.A.M.A., 142:566-569, lieb. 25,1950

$4-20-51$

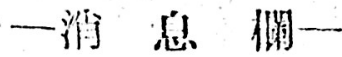

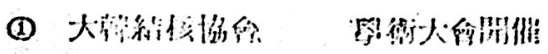

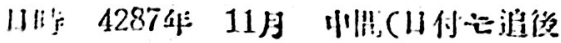
分结的)

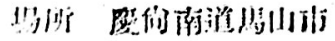

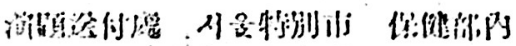

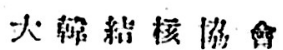

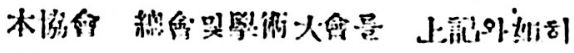

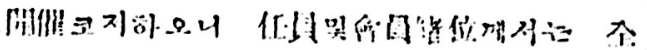

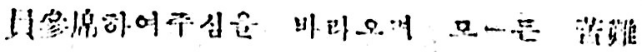

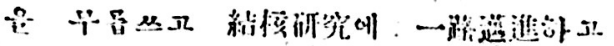

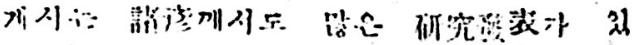
기귬 비륨나나

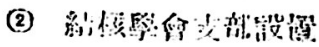

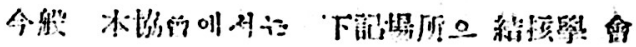

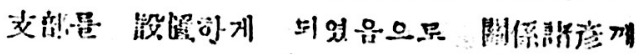

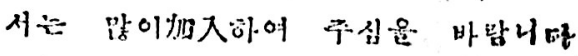

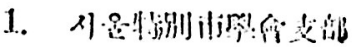

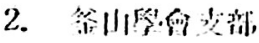

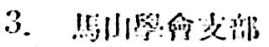

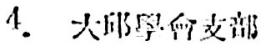

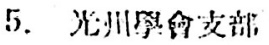

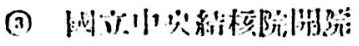

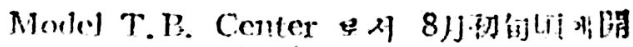
Biris:

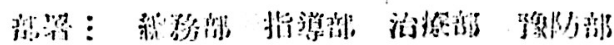

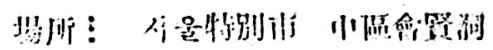

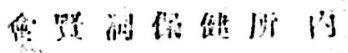

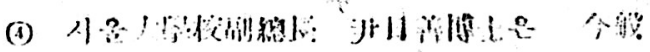
7

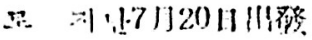

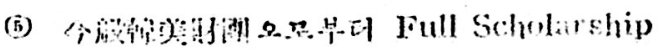

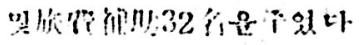

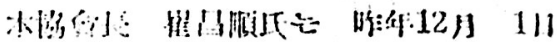

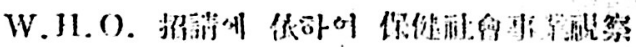

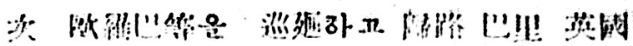

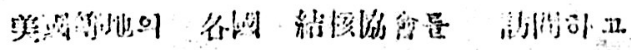

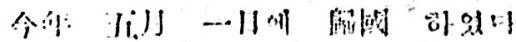

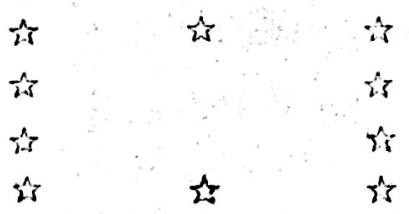

